\title{
Non-destructive holographic vibrometric testing of the adhesive joint in metal-polymer laminates (Rapid communication)
}

\author{
Jagoda Nowak-Grzebyta ${ }^{1), *)}$, Frans Meijer ${ }^{2)}$,Ewa Stachowska ${ }^{2)}$ \\ DOI: dx.doi.org/10.14314/polimery.2020.7.11
}

\begin{abstract}
The possibility to detect defects in polyamide-aluminum composites with pure adhesive connection using holographic vibrometric non-destructive testing (NDT) was investigated. Clear differences could be observed in the phase of vibration patterns and amplitudes, registered with nanometric resolution, between a correct and a defective adhesive connection.
\end{abstract}

Keywords: Non-destructive testing, adhesive joint, holography, vibrometry, metal-polymer complex, connection defect.

\section{Badanie nieniszczące połączenia adhezyjnego w laminatach polimerowo- metalowych}

Streszczenie: Zbadano możliwość wykorzystania cyfrowej holograficznej wibrometrii - nieniszczącej metody testowania (NDT) - do wykrywania defektów połączeń adhezyjnych w kompozytach poliamidowo-aluminiowych. Zaobserwowano istotne różnice między uzyskanymi rozkładami drgań i ich amplitudami, mierzonymi z nanometryczną rozdzielczością, w wypadku próbek z połączeniem adhezyjnym bez defektu oraz z defektem.

Słowa kluczowe: badania nieniszczące, adhezja, wibrometria, połączenie metal-polimer, defekt połączenia.

A pure adhesive connection between polymer and metal is known to be usually weak due to differences in elasticity. The latter also causes the resonant frequencies of the materials to be different. Such a connection can easily be destroyed using conventional testing methods for composites [1-4]. Only investigations using a very small vibration amplitude (in the order of $10^{-9} \mathrm{~m}$ ) can therefore be used in this case. Here the (resonant) deformation of material is several orders lower than when using fracture deformation. The development of non-destructive and non-contact methods to investigate composite laminates, as well as the designing and modelling process of the adhesive joint, has been the focus of much research [5-9]. Optical interferometric methods are very precise (to a fraction of nanometer) and also data collection is

\footnotetext{
1) Poznan University of Technology, Institute of Materials Technology, Division of Polymer Engineering, Piotrowo 3, 60-965 Poznan, Poland.

2) Poznan University of Technology, Institute of Mechanical Technology, Division of Metrology and Measurement Systems, Piotrowo 3, 60-965 Poznan, Poland.

*) Author for correspondence:

jagoda.pa.nowak@doctorate.put.poznan.pl
}

fast [10-14]. Our aim was to use non-destructive testing (NDT) - holographic vibrometry - to detect fastly millimetre size defects in an adhesive joint in layered polyamide-aluminum (PA6-AL) structures [15-17].

\section{EXPERIMENTAL PART}

\section{Materials}

Two sets of at least six samples connected adhesively (without any interlayer) have been measured in our experiments. The first set contained samples of aluminum - Al6061 (Metpartner, Żabiczyn, Poland) with polyamide 6 - PA6 (produced by Grupa Azoty, Tarnow, Poland) containing $10 \mathrm{wt} \%$ mica platelets (Al-PA6-M10). The second set of samples consisted of Al6061 and PA6 containing $10 \mathrm{wt} \%$ talc platelets (Al-PA6-T10). The filler particles mean longest dimensions were $7.4 \mu \mathrm{m}$ for Talc Extra 10 and $8.8 \mu \mathrm{m}$ for Mica 30 (both purchased from Aurum Chemicals, Katowice, Poland).

\section{Samples preparation}

The surface of the aluminum was firstly washed under running water with dish detergent; then 
degreased with isopropanol and after 2 minutes with acetone. The surface was next degreased with an alkaline solution $\left(\mathrm{NaOH} 10 \mathrm{~g} / \mathrm{dm}^{3}+\mathrm{Na}_{2} \mathrm{CO} 30 \mathrm{~g} / \mathrm{dm}^{3}\right)$ for 5 minutes and then rinsed with distilled water. After 20 minutes of chemical etching with an acid mixture $\left(\mathrm{H}_{3} \mathrm{PO}_{4} 74 \%+\mathrm{HNO}_{3} 4.6 \%+\mathrm{CH}_{3} \mathrm{COOH} 4.6 \%\right)$ the aluminum was rinsed with distilled water and cleaned with isopropanol in an ultrasonic cleaner for 10 minutes at $25^{\circ} \mathrm{C}$ and afterwards rinsed with acetone. The dimensions of the single metal sheets and single polymer parts were $60 \times 20 \mathrm{~mm}^{2}$ (length $\times$ width) each. The aluminum parts were $1 \mathrm{~mm}$ thick. The joints of the Al6061 plates with the PA6 plates, used as investigation objects (Fig. 1) were produce by compression molding at a temperature of about $320^{\circ} \mathrm{C}$ and cooled to the ambient temperature under a constant pressure of about $12 \mathrm{kPa}$. The overlapping surfaces of the polymer and metal parts were $20 \times 20 \mathrm{~mm}^{2}$. Prior to the heat induced connection of both materials a model type defect in the form of a groove (see Fig. 1) was shaped in some of the PA6 sheets, by locally heating of the polymer with a $1 \mathrm{~mm}$ thick steel plate at a temperature $300^{\circ} \mathrm{C}$. This defect was implemented in some samples in the central part of the polymer-metal joint across the sample and about $2 \mathrm{~mm}$ wide. This provided a translation symmetry across the sample, which allowed us to average the vibration patterns in this direction to obtain additional information (see Figs. 3-6).

\section{Methods of testing}

All samples were measured using the same procedure and set of parameters. A detailed description of the setup is described by us in paper [18]. We used an Optonor Vibromap-1000 digital holographic vibrometer [15] (Fig. 2 left side). In our case the sample is put into a nanometre vibration by means of a piezo transducer, inducing an oscillation with constant frequency in the tested materials, including the adhesive joint between them. The sample was mounted in a self-build holder (Fig. 2 right side, between the mirrors). Excitation of the sample by a sinusoidal signal from a function generator, as well as recording the hologram sequence is controlled by a special pro-

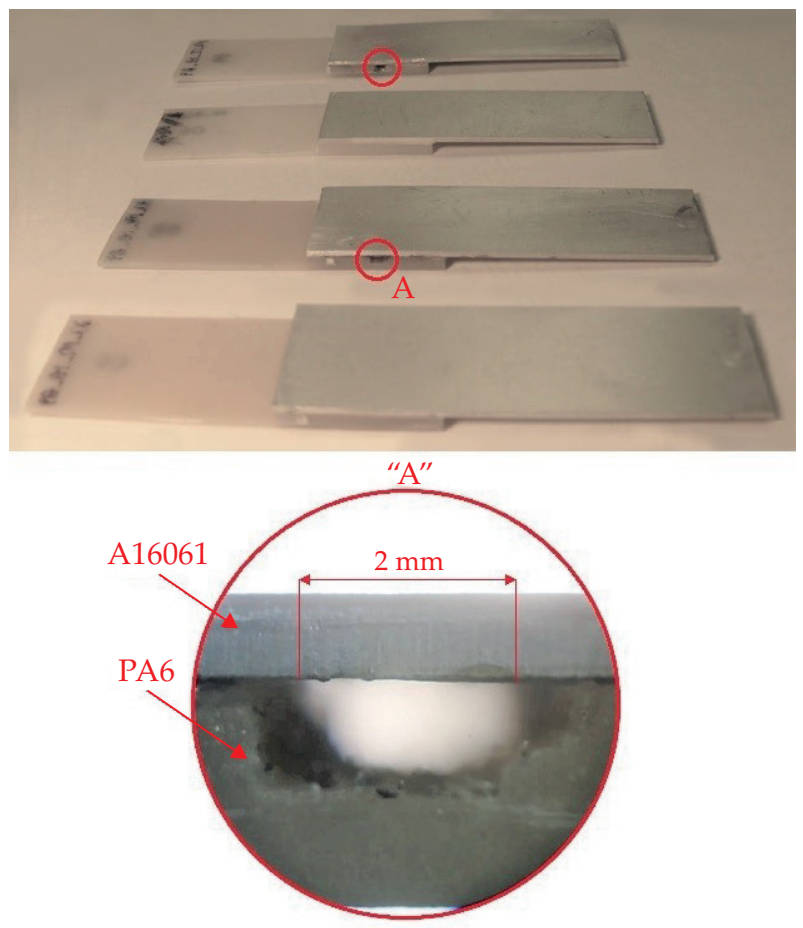

Fig. 1. Photo of a sample; the defects are marked with circles

gram ("Vibromap" by Optonor), the raw data were then evaluated with the statistical and visualization package R [19].

During a measurement we observed simultaneously the upper and the lower surface of the sample under study (Fig. 2 - A, B). The piezo transducer was placed on the polymer side in a clamp along with the sample. In order to determine resonant frequencies we tested all samples in the frequency range of $200-10000 \mathrm{~Hz}$ with a step-size of $100 \mathrm{~Hz}$ using piezo excitation voltages of $1 \mathrm{~V}$ as well as $5 \mathrm{~V}$. Based on our preliminary investigations we choose a frequency of $3200 \mathrm{~Hz}$ and an excitation voltage of $1 \mathrm{~V}$ to compare all samples investigated.

\section{RESULTS AND DISCUSSION}

The quality of the adhesive connection between Al6061 and PA6 was tested using both the amplitude and the
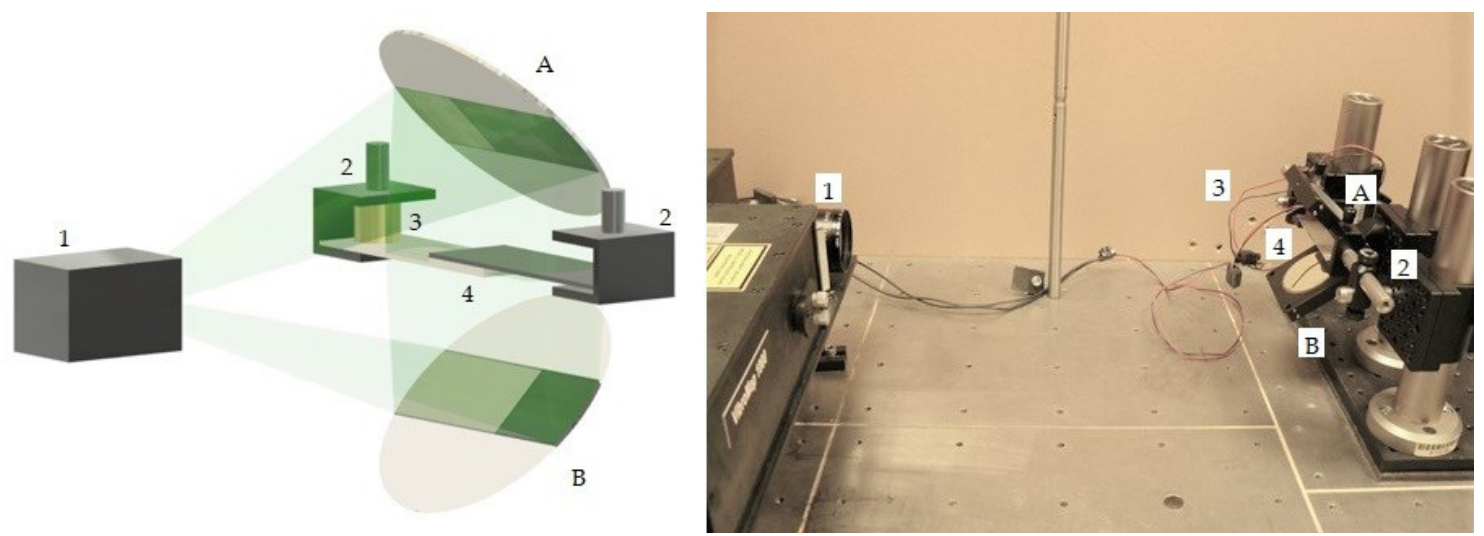

Fig. 2. Experimental setup with the sample holder and the piezo transducer: 1 - vibrometer, 2 - sample holders, 3 - piezo transducer, 4 - sample, A - upper surface of the sample reflected in the mirror, B - lower surface of the sample reflected in the mirror 
a)

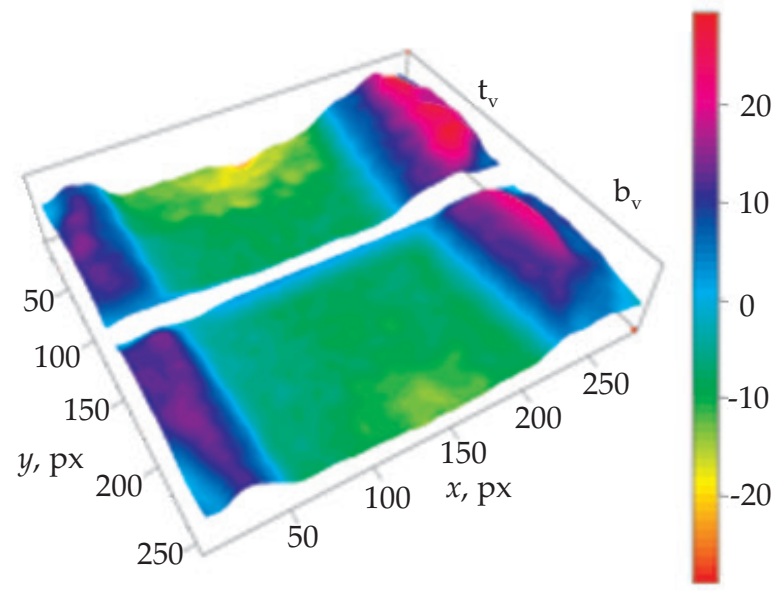

Amplitude, nm b)

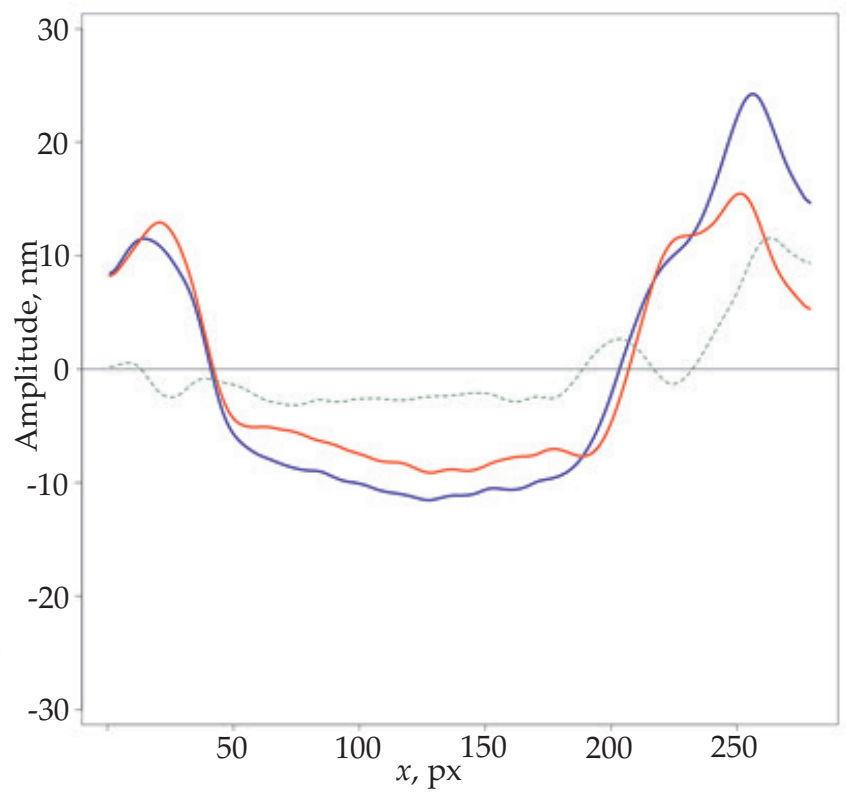

Fig. 3. a) 3D plot of the vibration pattern of the Al-PA6-M10 sample at one moment in the vibration cycle; tv - rear part, the top view; bv - front part, the bottom view; $x$ and $y$ axis - distance in pixels, $\mathbf{b}$ ) the amplitude in $\mathrm{nm}$, averaged over the $y$ direction at the moment selected; blue line - polymer side (bv); red line - metal side (tv); green line - difference between metal and polymer amplitude

a)

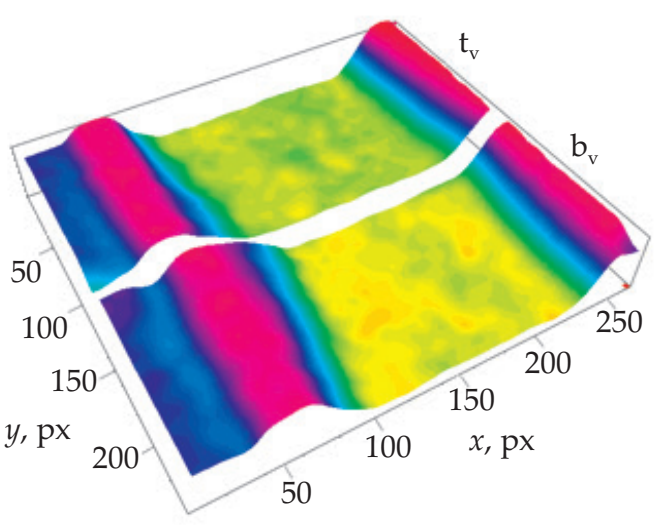

Amplitude, $\mathrm{nm}$

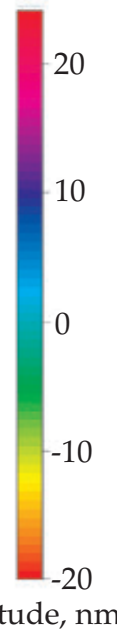
on both sides of the sample simultaneously, 30 times during one cycle. An example of a vibration pattern for an Al-PA6-M10 sample at one moment in time is given in Fig. 3 and for an Al-PA6-T10 sample in Fig. 4. We show the moment the amplitude of the part of the joint is maximal. phase patterns. The vibration patterns were registered b)

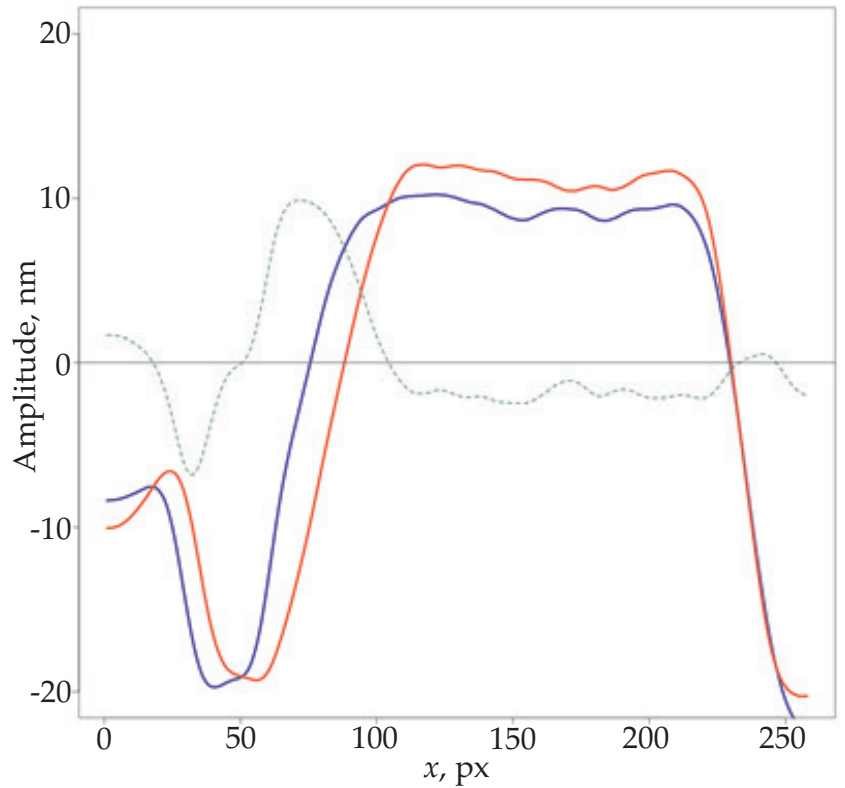

Fig. 4. a) 3D plot of the vibration pattern of the Al-PA6-T10 sample at one moment in the vibration cycle; tv - rear part, the top view; $\mathrm{bv}$ - front part, the bottom view; $x$ and $y$ axis - distance in pixels, $\mathrm{b}$ ) the amplitude in $\mathrm{nm}$, averaged over the $y$ direction at the moment selected; blue line - polymer side (bv); red line - metal side (tv); green line - difference between metal and polymer amplitude

In the case of samples without a joint defect we did not observed any significant difference between the vibration patterns for Al-PA6-M10 and Al-PA6-T10. Polymeric and metallic parts oscillated together with approximately the same amplitude (about $10 \mathrm{~nm}$ and a difference of about $2 \mathrm{~nm}$ ) and at the same phase. A well visible phase jump 
a)

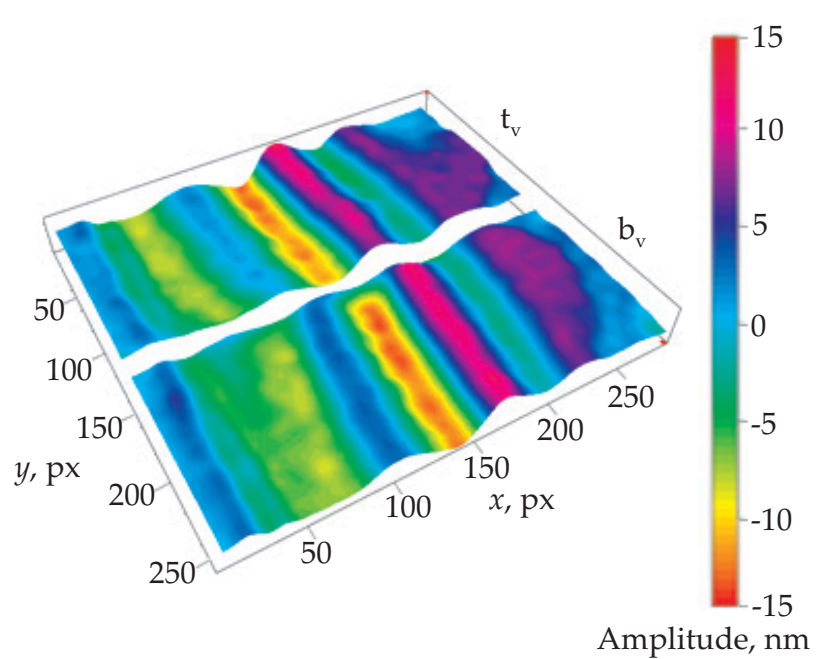

b)

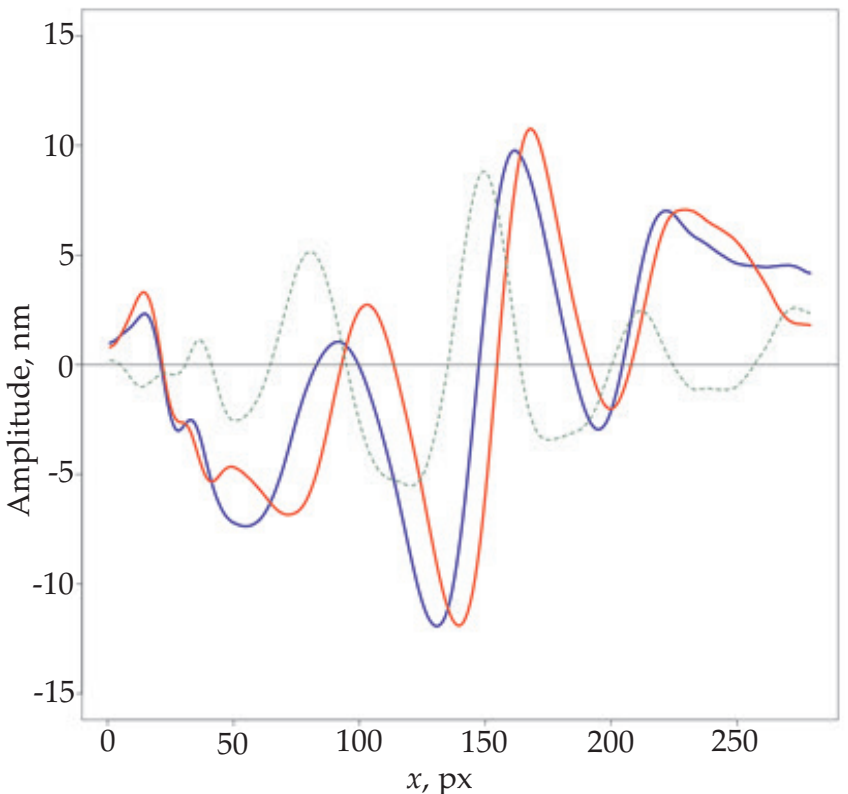

Fig. 5. a) 3D plot of the vibration pattern of the Al-PA6-M10 sample with a defect at one moment in the vibration cycle; tv - rear part, the top view; bv - front part, the bottom view; $x$ and $y$ axis - distance in pixels, $b$ ) the amplitude in nm, averaged over the $y$ direction at the moment selected; blue line - polymer side (bv); red line - metal side (tv); green line - difference between metal and polymer amplitude

a)

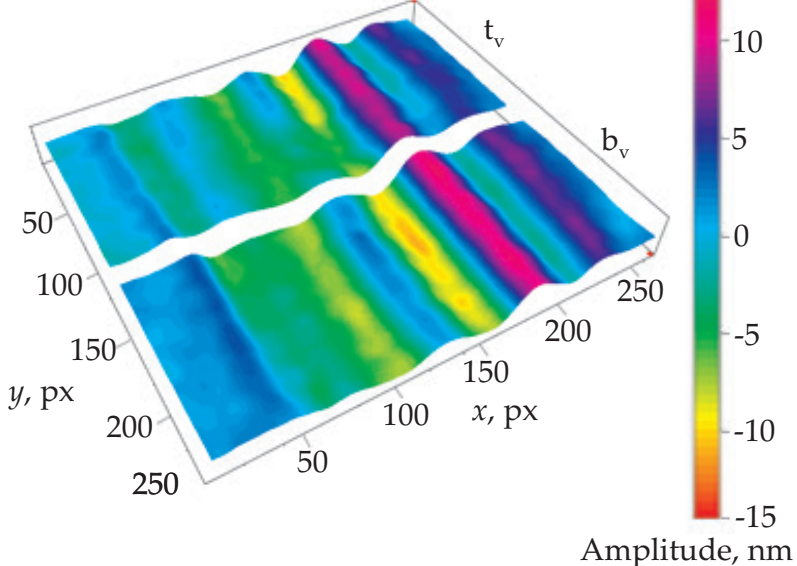

b)

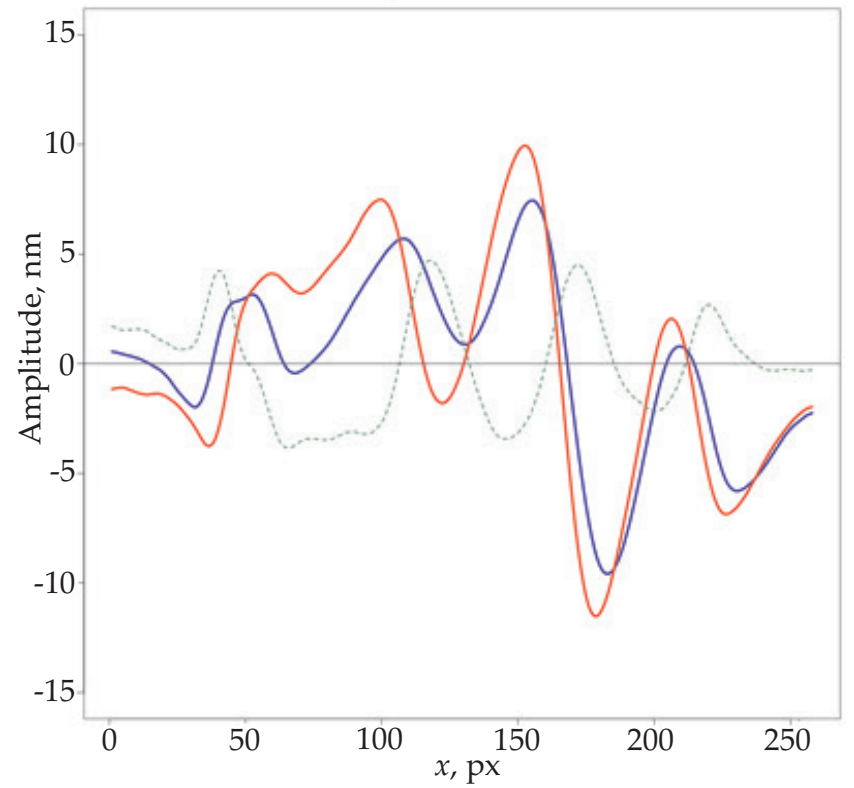

Fig. 6. a) 3D plot of the vibration pattern of the Al-PA6-T10 sample with a defect at one moment in the vibration cycle; tv - rear part, the top view; bv - front part, the bottom view; $x$ and $y$ axis - distance in pixels, $b$ ) the amplitude in nm, averaged over the $y$ direction at the moment selected; blue line - polymer side (bv); red line - metal side (tv); green line - difference between metal and polymer amplitude

corresponds to the borders of the overlapping parts. In the Figs 5 and 6 we present the vibration patterns for the modified samples with a defect (see Fig. 1). These samples show a different vibration pattern with a significantly higher difference in amplitude of both sides in the whole area of the joint and especially at the defect, which in this way could be localized. This difference is up to $8 \mathrm{~nm}$ for Al-PA6-M10 and $5 \mathrm{~nm}$ for Al-PA6-T10.

Summarizing this part of our investigations we can state that in the case of a non-defect sample, i.e. with continuous adhesion, even between two materials with various elastic properties, the vibration pattern has a constant ampli- 
a)
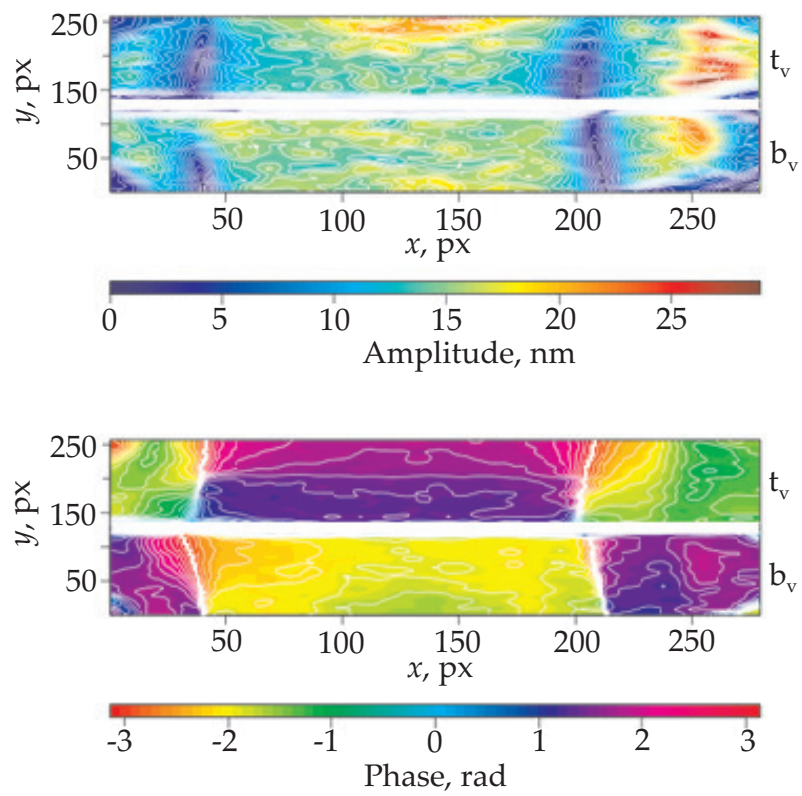

b)
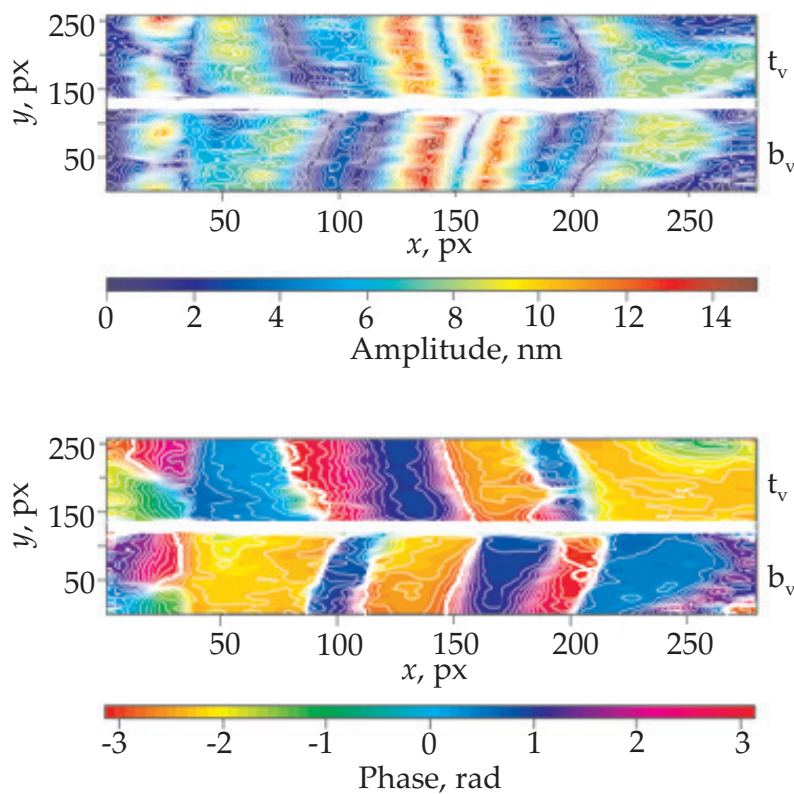

Fig. 7. Top and bottom views of amplitude and phase patterns of the A1-PA6-M10 sample with an adhesive connection; the joint area stretches from about pixel 40 to about 210: a) without defect, b) with a defect in the middle of the sample, around pixel 150; the excitation frequency was $3200 \mathrm{~Hz}$, tv - metal, bv - polymer; the size of the visible part of the sample is $40 \times 20 \mathrm{~mm}$ (the $x$ and $y$ scales in the figures are different)

a)
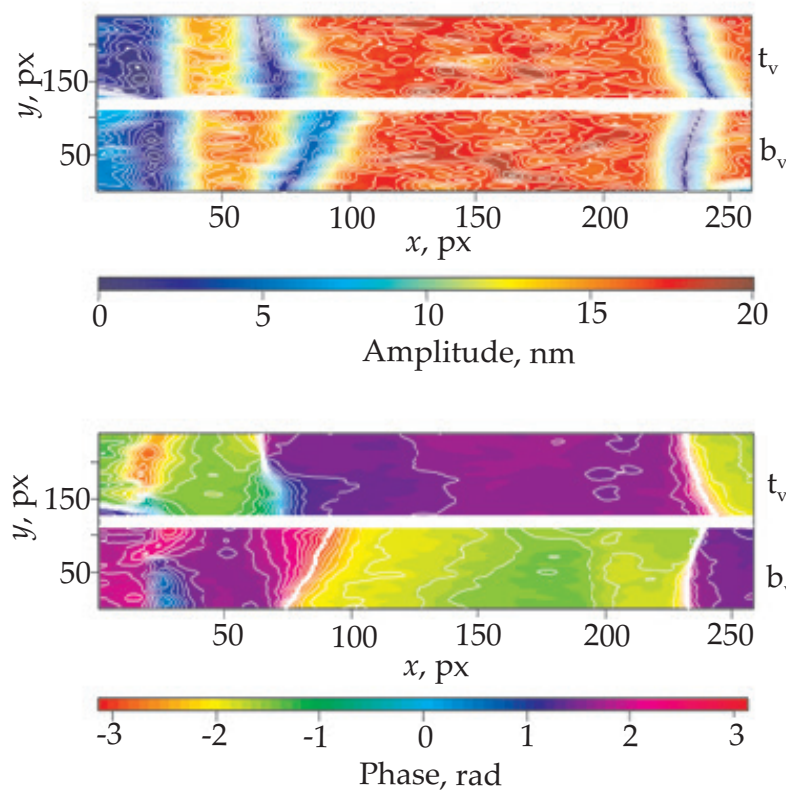

b)
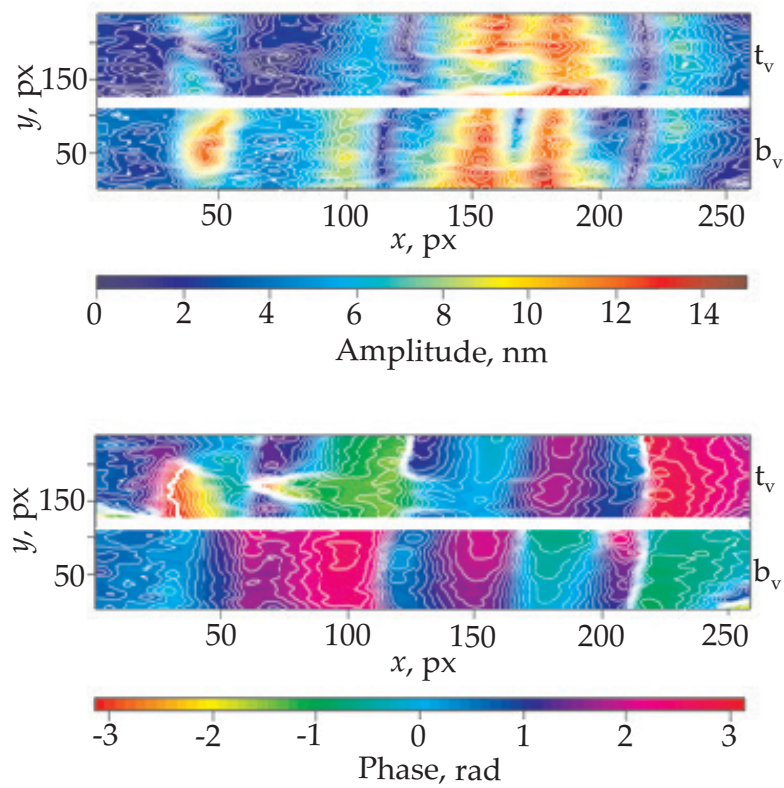

Fig. 8. Top and bottom views of amplitude and phase patterns of the Al-PA6-T10 sample with an adhesive connection; the joint area stretches from about pixel 70 to about 235: a) without defect, b) with a defect in the middle of the sample, around pixel 170; the excitation frequency was $3200 \mathrm{~Hz}, \mathrm{tv}$ - metal, bv - polymer; the size of the visible part of the sample is $40 \times 20 \mathrm{~mm}$ (the $x$ and $y$ scales in the figures are different)

tude over the whole length of the connection. An adhesion defect leads on the contrary to a locally higher amplitude as well as multiple maxima and a significant difference between the amplitudes of both joint components.

We also examine the connection using pictures of: the oscillation amplitude and the phase distribution at one moment of the oscillation.
See for the Al-PA6-M10 samples - Fig. 7 and for the Al-PA6-T10 samples - Fig. 8.

The difference between Fig. 7 and Fig. 8 is the composition of the polyamide 6 composite, Al-PA6-M10 and Al-PA6-T10, respectively. As again follows from the figures the defects caused significant, well visible changes in the vibration pattern in the area of the defect. 


\section{CONCLUSIONS}

Using digital holographic vibrometry to study adhesively bounded laminates, composed of two materials with various elastic properties, we can clearly detect defects in adhesive connections. This makes this method very suitable for NDT of metal polymer laminates. The difference between samples with and without defects in the adhesive connection area can be observed in a wider frequency range than we described here. We have found that even after many repetitions on the same sample the results are very much the same: proof of a high reproducibility. We ascertained that the samples investigated were not damaged by our measurements, as should be the case for an NDT-technique. This makes this method suitable for laboratory testing samples, when developing light construction elements, like metal-polymer adhesive joints, as well as in a production line.

\section{ACKNOWLEDGMENTS}

We kindly acknowledge the provision of the metal and polymer sample parts by Oliwia Trzaska from the Wroclaw University of Science and Technology. We also thank Tomasz Sterzyński from the Poznan University of Technology for insightful discussions.

This work was financially supported by the Polish National Centre of Science; contract grant number: OPUS2016/21/B/ ST8/03152. ES acknowledges partial support by project 02/220SBAD/1501 of the Poznan University of Technology.

\section{REFERENCES}

[1] Kurzydłowski K.J., Boczkowska A., Schmidt J. et al.: Polimery 2005, 50, 4, http://dx.doi.org/10.14314/polimery.2005.255

[2] Francis D., Tatam R.P., Groves R.M.: Measurement Science and Technology 2010, 21, 102001. https://doi.org/10.1088/0957-0233/21/10/102001

[3] Hung Y.Y.: Optical Engineering 1983, 21 (3), 213391. https://doi.org/10.1117/12.7972920

[4] Koeon J.H., Jung J.W., Kim T.H. et al.: Composite Structures 2006, 75, 192. https://doi.org/10.1016/j.compstruct.2006.04.013

[5] Amancio Filho S.T., dos Santos J.F., Blaga L.-A.: "Joining of Polymer-Metal Hybrid Structures: Principles and Applications", John Wiley \& Sons, 2018, p. 29-54.

[6] Kawai M., Arai Y.: Composites Part A: Applied Science and Manufacturing 2009, 40, 1900. https://doi.org/10.1016/j.compositesa.2009.07.014

[7] Matsuzaki R., Shibata M., Todoeoki A.: Composites Part A: Applied Science and Manufacturing 2008, 39, 154. https://doi.org/10.1016/j.compositesa.2007.11.009

[8] da Silva L.F.M., Adams R.D.: International Journal of Adhesion and Adhesives 2018, 83, 1 .

https://doi.org/10.1016/j.ijadhadh.2018.02.017
[9] da Silva L.F.M., Adams R.D.: International Journal of Adhesion and Adhesives 2007, 27, 216. https://doi.org/10.1016/j.ijadhadh.2006.04.002

[10] Kosmatka J., Foerster Ch., Valdes A.: "An Improved Ground Vibration Testing Approach of Flight Vehicle Structures Using a Scanning Laser Vibrometer", Materials from Structural Dynamics and Materials Conference, Honolulu, Hawaii, 23-26 April 2012, https://doi.org/10.2514/6.2012-1884

[11] Martarelli M., Chiariotti P., Pezzola M. et al.: "Delamination Detection in Composites by Laser Ultrasonics", Materials from 11th International Conference on Vibration Measurements by Laser and Noncontact Techniques, Ancona, Italy, 24-27 June 2014, pp. 405-412.

[12] Khan A.A., Dai Z., Cortina M.S. et al.: "Localized Elastography Map of Human Cornea Through Surface Vibrations", Materials from ASME 2013 International Mechanical Engineering Congress and Exposition, San Diego, California, USA, 15-21 November 2013, IMECE2013-64016, V03BT03A049, 4 pages.

[13] Nutakor Ch., Semken R.S., Heikkinen J.E. et al.: "Layered Sheet-Steel Damping Estimation Using Optical Vibrometry", Materials from ASME 2015 International Design Engineering Technical Conferences and Computers and Information in Engineering Conference, Boston, Massachusetts, USA, 2-5 August 2015, DETC2015-46867, V008T13A036, 10 pages.

[14] Krasnoveikin V.A., Konovalenko I.S.: “Development of the Noncontact Approach to Testing the Dynamic Characteristics of Carbon Fiber Reinforced Polymer Composites", Materials from 12th International Conference on Mechanics, Resource and Diagnostics of Materials and Structures, MRDMS 2018, Ekaterinburg, Russian Federation, 21-25 May 2018, 040048-1-040048-5.

[15] https://optonor.com/vibromap-1000/, accessed 24 March 2020.

[16] Aryan P., Kotousov A., Ng C.T. et al.: Structural Control \& Health Monitoring 2016, $24,4$. https://doi.org/10.1002/stc.1894

[17] Černecký J., Božek P., Pivarčiová E.: Journal of Electrical Engineering 2015, 66, 53. https://doi.org/10.1515/jee-2015-0008

[18] Nowak J., Meijer F., Bula K. et al.: “Non-destructive testing of metal-polymer laminates with a digital holographic vibrometer", submitted for publication in Journal of Nondestructive Evaluation.

[19] R Core Team (2017). R: "A language and environment for statistical computing", R Foundation for Statistical Computing, Vienna, Austria, https://www.r-project.org.

Received 3 IV 2020. 